\title{
Crowdfunding: Understanding Diversity
}

\section{Mia Gray and Bryan Zhang*}

Since the 2008 financial crisis, crowdfunding has grown into a small but significant global industry, which has largely by-passed the traditional banking sector. Crowdfunding is estimated to have reached $€ 3$ billion worth of transactions across Europe in 2014 (Zhang et al., 2015). Crowdfunding allows individuals to pool resources to provide capital to firms, ideas, places and projects. For some commentators, crowdfunding represents a real alternative to a discredited banking sector. Crowdfunding supporters claim the sector represents an alternative to the traditional banking sector which facilitates new ways to accumulate and allocate capital (Kim and Hann, 2013; Shiller, 2012). Shiller applauds the rise of crowdfunding as part of the "democratization of finance", which enables individuals to determine where and how their savings and investments are made (Shiller, 2013).

The mainstream banking system was profoundly implicated in the 2008 financial crisis as banks created sophisticated financial tools which functioned to encourage excessive speculation and risk on a global scale (Blyth, 2013; Aalbers, 2015). The global banking crisis in 2007/08 was transformed into a sovereign debt crisis and the widespread adoption of austerity policies on both national and urban scales (Kitson et al., 2011; Donald et al., 2014). This led many individuals to search for alternatives and, in particular, less financial intermediation between the saver and borrower, the investor and investee. Aalbers (2015) argues that this growth has created a significant increase in the sources of credit supply and a reshaping of financial geographies across all scales. Whether this trend should be celebrated or condemned is debatable. While Shiller applauds the "democratization of finance", Erturk and his colleagues are critical of the "broadening and deepening" of access to capital markets for ordinary individuals (Erturk et al., 2007).

Although crowdfunding has received much popular press, it remains on the fringes of academic scrutiny. There has been little systematic academic attention paid to the levels and areas of growth, the behaviour of the industry, and the spatial and financial implications of this growth. We conceptualise crowdfunding as technology-enabled online financial channels, instruments and activities that allow individuals and organizations to participate in capital formation and allocation processes, which have emerged outside of the traditional financial system (e.g. regulated banks and capital markets). This chapter explores a multitude of different crowdfunding financial models utilising primary survey data from over 15,000 respondents, as well as a primary transactional dataset containing over a million microtransactions totalling $£ 1$ billion. To date, very little quantitative work has been conducted on this burgeoning phenomenon and there exist few qualitative studies; thus, this paper will

\footnotetext{
* The authors would like to thank Mingfeng Lin, Peter Baeck and Liam Collins for their generous help and input in making this chapter possible.
} 
fulfil an important function in providing a critical and systematic analysis of an emerging industry.

The term crowdfunding covers a diverse set of practices, from supporting emerging art projects to lending and borrowing money, to investing in new business ventures and supporting local charities. The term is used to understand the financial support of friends and family to complete strangers making each other short-term loans, and to institutional actors finding new investment opportunities. However, by conflating all these phenomena into one, the term hides as much as it reveals. We argue that, to understand the phenomena, the term must be broken down into its constituent parts, which display different dynamics and geographies.

\section{Geography and the Financial Sector}

One crucial question is the extent to which these emerging financial phenomena may change the geography of the mainstream financial system. Almost 25 years ago, O'Brien claimed that "geographical location no longer holds sway in finance... money, being fungible, will continue to try to avoid and will largely succeed in escaping the confines of geography" (1992:1). O'Brien argued that deregulation, financial innovation, and the adoption of enabling ICT deemphasized the importance of geography and location for financial firms, financial flows and access to financial services. However, geographers have long critiqued this argument and emphasized the mainstream financial sector's overconcentration of capital and power in financial centres such as London and New York, its distinct locational biases in the distribution of capital, and strong spatial patterns of financial exclusion (Klagge and Martin, 2005). If anything, Garretson and his colleagues argue that the "spatial concentration of banks, investment houses and other financial institutions in the major national (and global) financial centres has not dramatically lessened: indeed in many respects it has increased, as has the financial specializations of those centres and the competition between them" (Garretson et al., 2009:144).

In the UK, the nation's highly centralized finance sector - the main financial institutions, capital markets, and financial service firms - is firmly entrenched in London and the South East of the country. London's dominance in finance arises from and is reinforced by its function as a "portal through which global financial developments and perturbations are diffused - directly and indirectly - across domestic and capital markets" (Klagge and Martin, 2005:389). Klagge and Martin show that the level of financial concentration in London is cumulative and leads to a spatial bias in the flows of equity capital to firms in other regions of the UK. The argument is that the information-gathering and monitoring functions necessary for banks to lend to small firms are spatially sensitive and this results in funds being biased towards firms in close proximity to the banks. The cumulative nature of the growth resulting from the centralized and concentrated finance industry is highlighted by Wójcik (2009). He shows that firms that are located in financial centres, such as London, are more likely to go public than firms in other regions. Thus, these firms find funds for expansion and growth in a manner less likely for firms in other regions. 
Likewise, there is a great deal of literature which shows that other parts of the finance industry, such as venture capitalists, also display a similar spatial pattern. Mason and Harrison (2002) show that, like the mainstream financial institutions, venture capitalists are concentrated in London and the South East, as are their investments. Likewise, Martin et al. (2003) find a strong regional bias in the UK's venture capital industry. They find that venture capital investments are highly concentrated in London and the South East, reinforcing existing patterns of regional concentration of economic activity. Proximity enables a "hands on" business model, where financial support is accompanied by higher levels of engagement and monitoring of the funded firm. Smaller firms, in regions further away from London, are likely to find it more difficult to raise venture funds.

Therefore, the mainstream financial industry has a clear locational bias that is producing a large regional gap in funding for small firms outside of London and the South East. To what extent might this locational bias be challenged by new financial intermediaries represented by crowdfunding? To answer this, we explore the rise of the newest segment of the financial industry, its diversity and its spatial patterns.

\section{Understanding the Rise of New Financial Intermediaries}

There exists a large amount of established literature on the economic geography of money and finance (Martin, 1999; Leyshon and Thrift, 1997; Clark, 2005). Broadly, these studies explore the variation of financial systems across and through space and, in particular, the tensions between the national and regional organization of finance and financial systems' global tendencies. Although few geographers explored the scale and scope of crowdfunding as an emerging form of finance, they have contributed to our understanding of the crowdfunding phenomena by stressing the importance of space to contemporary capital formation.

David Harvey's work has focused for decades on Marxist interpretations of the financial system (Harvey, 1982, 1989, 2010). He has continued to argue that capital is a process of circulation and that to understand the process we must understand the logic, structure and organization of the circuits of capital. Harvey's political economy approach leads him to emphasize the classic split between productive and finance capital. He analyses capital's tendency to switch circuits, or to move investments from capital's primary circuit of investment in industry to the secondary circuit of the built environment. In later works, Harvey $(1989,2010)$ expands this point to include switching into the financial circuit, and the complex relationship between the different circuits as illiquid forms of capital seek more liquid forms through financialization and securitization. However, all financial circuits tend to be homogenized in Harvey's treatment. Additionally, Harvey's theory of capital switching is difficult to show empirically (see Beauregard, 1994; Gotham, 2009), and it is often unclear to what extent investment is actually withdrawn from one circuit of capital to another. Although crowdfunding is not explicitly addressed in this debate, we argue that the expansion of these alternative forms of capital formation might, at least conceptually, represent another circuit for capital. Further, its potential as an alternative to the traditional banking system means it has the potential to create different financial, social and spatial consequences 
compared with other financial circuits. However, to understand this fully, the processes and practices which shape these circuits must be examined.

Another important contribution of economic geographers that helps us to understand the phenomena of crowdfunding is the continued emphasis on the social nature of capital (Martin, 1999; Leyshon and Thrift, 1997). Martin (1999:11) argues that financial markets are "structured networks of social relations, interactions and dependencies". Leyshon and Thrift (1997), however, stress the set of social practices which create and recreate financial spaces on different scales. They argue that, although money has the potential to be placeless as part of global flows of capital, monetary practices are forged in particular places. New forms of money and capital formation produce new social practices, which combine with older forms of monetary practice into innovative combinations. They examine the culture of money - the shared norms, practices and conventions which uphold and extend the system of money. Pollard and Samers (2013) illustrate this in their work on Islamic finance, which brings together Western and Islamic financial rules, practices and norms not often articulated in finance - such as fairness, justice and transparency.

One of the strengths of the financial geography literature is the importance it gives to institutional and regulatory changes, which constantly reshape and structure the industry. As part of this, Leyshon and Thrift discuss the social practices of regulation and argue that established regulatory boundaries continue to link money to place and social practice. In their discussion of virtual forms of money, they highlight the importance of trust and its maintenance through expert systems and knowledge structures (state regulation, monitoring, surveillance) which act to guarantee expectations across space (Giddens, 1990). This is particularly important in new sectors; Leyshon and Thrift, for example, argue that the actors in novel markets can often benefit from monopoly profits because the area is not yet regulated. Martin (1999) makes a similar point that firms will escape regulatory oversight by moving between regulatory spaces and seeking regulatory gaps. However, neither Martin nor Leyshon and Thrift expand upon the conditions under which new market agents may actually promote regulation as part of an expert system that will function to enhance trust.

The focus on the changing role of institutional actors is a useful one for understanding the role of the crowdfunding platforms. Martin and Turner (2000) detail the regulatory changes in the UK in the 1980s, which resulted in the demutualization of Building Societies and the decline of Building Societies as a financial alternative to the traditional banking sector. Martin and Turner highlight how the regulatory changes promoted the political agenda of "popular capitalism". Likewise, Clark (2000) and Dixon and Monk (2012) highlight the rise of institutional investors, such as the large pension and sovereign wealth funds, who have become important actors in understanding the importance of institutional investors in contemporary capital formation and distribution. Clark (2005:99) argues:

If we are to understand the economic landscape of twenty-first century capitalism, it should be understood through global financial institutions, its social formation and investment practices. 
The rise of crowdfunding has created new institutional intermediaries - crowdfunding platforms - which shape the processes and practices of this new form of capital formation. Understanding these platforms, the role they play in capital formation, and how they create certain practices and conventions of crowdfunding, requires more research.

Other disciplines have been quicker to examine the rise of crowdfunding. Most of the academic attention given to crowdfunding comes from the fields of business, finance (Colombo et al., 2015; Belleflamme et al., 2014; Mollick, 2014) and law (Griffin, 2013; Schwartz, 2013; Bradford, 2012). This literature is predominantly focused on the motivations for crowdfunding, the determinants of success and the legal restrictions of equity-based crowdfunding. However, some spatial issues also feature strongly in this literature. One important debate in the business literature is focused on the extent to which crowdfunding functions to eliminate the importance of distance between investors and the projects or firms that receive funding. Focusing on Kickstarter, a large US-based platform which specializes in cultural projects, Mollick (2013) argues that geography is important in understanding crowdfunding in two ways. First, Mollick shows that crowdfunding results in an uneven distribution of funds to cultural projects around the US. Second, Mollick finds geographic patterns in the production of the cultural product itself. For example, that regional specialization (e.g. country music in Nashville, Tennessee) is reflected in the Kickstarter projects. Agrawal and his colleagues in the US have conducted one of the larger studies of the industry, exploring crowdfunding's ability to eliminate the "friction of distance" between investors and small, early-stage artistic projects that successfully receive funding. Agrawal et al. (2011) followed musicians seeking funding to see if crowdfunding relaxes geographic constraints on fundraising. They found that, although funders of successful projects were geographically dispersed, local investors still played an important role - they invested relatively early (often having a personal connection with the artist-entrepreneur), which served to signify the quality of the project to other potential investors. Agrawal et al. conclude that crowdfunding does not remove, but does relax, geographic constraints among funders.

Unlike the studies discussed above, Lin and Viswanathan (2014) focus on a debt-based crowdfunding platform to see if investment behaviour is different from the support or donation models discussed in the arts-based examples above. Lin and Viswanathan explore the extent to which the "home bias" documented in traditional finance continues to be displayed in debt-based crowdfunding, where the crowd invests in an early-stage firm. Lin and Viswanathan point out that home bias, where transactions are more likely to occur between parties in the same geographical area, is considered a sub-optimal behaviour in economics, leading to inefficiencies in the market. They find that, although crowdfunding has the potential to make home bias less relevant, lenders still favour investors in their own state.

These studies all suggest that spatial factors remain important in understanding how crowdfunding functions as a mechanism to distribute finance and the extent to which it might vary from, or reinforce, more traditional sources of finance. However, Mollick and Agrawal et al.'s findings are based on platforms which specialize in cultural projects. They assume the findings hold for other parts of the crowdfunding sector, but we do not know the extent to 
which the same patterns might hold over other burgeoning parts of the industry. Lin and Viswanathan's study is interesting in its focus on a debt-based platform, but is limited by the large spatial scale of their data. That is to say that measuring home bias on a state scale in the US might lose meaning in large and diverse states, such as California or New York.

\section{History of Crowdfunding}

Different forms of crowdfunding - where individuals pool resources to provide capital to firms, ideas, places and projects - have a longer history than we might initially think, but how we view crowdfunding fundamentally affects which antecedents are held up as precursors of the contemporary crowdfunding phenomena. One early and often-cited example of a donorbased crowdfunding campaign is Joseph Pulitzer's drive to fund the pedestal of the Statue of Liberty in 1885. As editor of the New York daily newspaper, The World, Pulitzer started a campaign encouraging individuals to make small donations, which successfully raised over $\$ 100,000$. However, what made this campaign interesting was the fact that not only were many donors encouraged to participate, no matter how small the donation, but that the methods used to garner support, in many ways, mirror today's technologically-mediated crowdfunding campaigns. Davies (2014) highlights that Pulitzer's newspaper campaign promoted a mutual awareness and collective identity of supporters by publishing the name of every single backer, often accompanied by quotes and personal stories. The paper also published daily updates on the progress of the campaign, which created an "in-time" dynamic and charted progress towards the fundraising goal. Both methods still feature prominently in many contemporary crowdfunding campaigns and remind us that the technological infrastructure of modern campaigns allows, but does not determine, the phenomena (ibid).

However, we need to look further afield for antecedents for other types of crowdfunding. We can see elements of the lending crowdfunding models in the rise of different alternative financial institutions such as building societies, credit unions and micro-loan funds (Martin and Turner, 2000; Fuller, 1998; Morduch, 1999). For example, Martin and Turner (2000) detail the growth of building societies in the UK - mutual societies owned by their members, or savers, who invested in local mortgages. They show that, while confined by law to providing first-time mortgages and to the retail savings which financed the mortgages, the building societies provided non-profit financial institutions that were often anchored in localities. Thus, building societies allowed many small savers to lend their money to fund local mortgages for first-time buyers. However, regulatory change in the guise of the 1986 Building Society Act led the sector to restructure, to break the link with local members and function more like traditional banks (Leyshon and Thrift, 1997). In a similar vein, Fuller and Jonas (2003) critically examined the role played by credit unions as a cooperative form of local banking, whereby savings of the community are pooled in order to lend to other members of the community or workplace. Fuller and Jonas highlight regulatory and competitive changes which mitigated against the model functioning as a real alternative to the mainstream financial institutions.

Finally, many scholars have often looked to the venture capital industry as a precursor for equity-based models of crowdfunding and argue that crowdfunding functions to democratize 
the seed capital funding model (Mollick, 2014; Schwienbacher and Larralde, 2010). Mollick contends that much of the venture capital model, such as the search for indicators of quality of the project and team, can be used equally well by crowdfunding backers. He finds that high-quality projects tend to get funded and that quality signals are magnified through a network of backers. Thus, the "crowd" of supporters can function like the networks supplied by venture capitalists.

\section{Understanding crowdfunding diversity through empirical studies}

We argue that, while the burgeoning literature on contemporary crowdfunding highlights a broad interest in the phenomena, our conceptual and empirical understanding of crowdfunding is hampered by the many studies which treat the industry as one homogeneous whole. This literature suffers from the tendency to examine one particular model (e.g. donation-based crowdfunding or peer-to-peer lending) or one particular industry vertical or sub-sector (e.g. arts- or music-based investment), with the assumption that their findings apply to the entire crowdfunding field. Thus, the emerging crowdfunding literature often suffers from the fallacy of composition (e.g. Mollick, 2013) and the lack of a clearly-defined taxonomy.

We argue that, in order to understand the motivations and the effects of "the crowd" as types of financial flows through alternative financing channels, academic studies must examine the diversity of crowdfunding. This chapter explores the different models hidden by the term "crowdfunding". To accomplish this, we examine donation-, reward- and equity-based crowdfunding models, debt-based crowdfunding models including peer-to-peer consumer and business lending, debt-based securities as well as invoice trading and community shares. We argue that each of these market segments of crowdfunding has different funding mechanisms, characteristics, motivations, and manifest varying geographies of financial transactions.

To understand the diversity and dynamics of the crowdfunding sector, we enlisted the support of the largest 26 UK-based crowdfunding platforms, which function to mediate between funders and fundraisers. Besides surveying platform operators directly, we also worked with the platforms to conduct surveys of funders and fundraisers based on their database between May and September 2014. Although it is difficult to know our response rate, since the universe of all potential respondents is unknown, we received survey responses from 15,685 individuals and businesses that have participated in one of the different crowdfunding models above. Our surveys produced quantitative data across eight models of crowdfunding, from equity-based crowdfunding to peer-to-peer business lending, in order to understand the distinct mechanisms and dynamics driving each specific model. In addition, with cooperation from these leading crowdfunding platforms, we also collected and analysed a million granular-level micro-transactions totalling $£ 1$ billion. These one million micro-transactions were extracted from the platforms' sanitized operating database (i.e. after deleting personal and financial information) and contained detailed information in regard to the crowdfunding transactions that took place. Besides the loan/equity offering information, auction/bidding data and repayment information, the funders and fundraisers' four-digit postcode data were also captured. Relying upon this largest academic crowdfunding database to date, we were 
able to derive, capture, analyze and aggregate important information for each crowdfunding model, such as the average amount of fundraising, average number of funders per deal and average contribution per funder.

\section{Diversity in Market Function and Size}

As argued above, one of the problems with the academic treatment of crowdfunding is that many scholars use the term broadly to refer to distinct, if related, models. In this section, we examine the market function and size of various models of crowdfunding.

When people mention crowdfunding, both in popular culture and academic studies, they often refer to either donation- or reward-based crowdfunding, which have risen in prominence with the success of platforms such as Kickstarter and GoFundMe. However, as clearly shown in Figure 1 below, the two largest models of crowdfunding in the UK are both debt-based crowdfunding models. The largest is the peer-to-peer business lending sector. Peer-to-peer business lending comprizes secured or unsecured debt-based transactions between individuals and businesses with an established trading history, most of which are SMEs.

Crucially, peer-to-peer business lending has emerged as an alternative source of SME funding, which allows some small firms to sidestep traditional bank lending. This segment of the crowdfunding market has grown rapidly since the 2007/08 banking crisis, as borrowers try to find alternatives to the traditional bank loans. Our data show that the majority of SMEs who obtained finance in this way had sought funding from sources such as banks (79\%), public funders (19\%), and venture capitalists $(12 \%)$ before obtaining finance through crowdfunding. The model allows many individual lenders to contribute to any one loan, usually through an auction process, thus "pooling" investment and risk amongst a large number of lenders. In 2014, peer-to-peer business lending accounted for $£ 749 \mathrm{~m}$ worth of loans and makes up around $43 \%$ of the total crowdfunding market volume. Although an important phenomenon to understand, to put this in perspective, traditional bank lending to SMEs in the UK during the same period totalled £53.4 billion (Bank of England, 2015). Despite this, supporters see signs of Shiller's "democratization of finance" in the rise of this crowdfunding model (Shiller, 2013).

Figure.1 2014 UK Alternative Finance Market Volume by Model

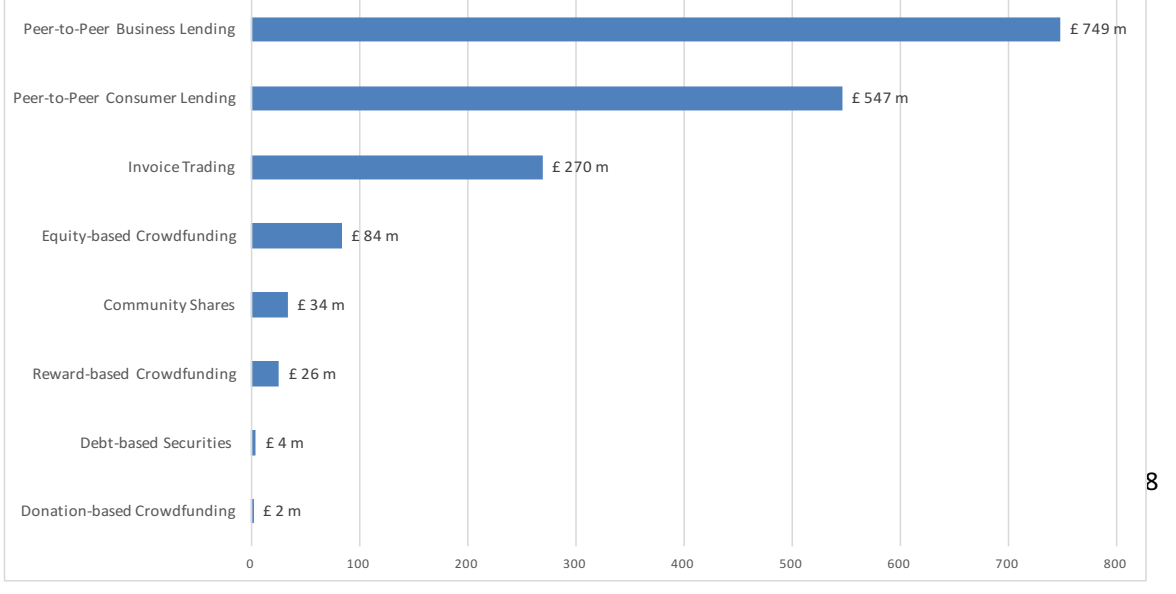


As Figure 2 demonstrates, the average peer-to-peer business loan size in the UK is $£ 73,222$. It typically takes 796 individual lenders to fund one loan with an average contribution of $£ 92$. It is important to note that the data on peer-to-peer business lending also includes secured loans in the real estate sector, which provides finance capital for small and mid-sized real estate developers. This particular segment of peer-to-peer business lending had a much larger average loan of roughly $£ 662,000$ (ibid) and is dominated by fewer investors per loan. Paradoxically, as many borrowers try to find alternatives to the large finance firms, we can also see that many of the funders for peer-to-peer real estate business lending are already dominated by large institutional investors, such as hedge and pension funds, attracted to the returns in peer-to-peer business lending, which can range from $8 \%$ to $18 \%$ depending on the loan risk profiles and maturity.

The second largest model of crowdfunding also has the potential to challenge the role of the traditional banking sector. The peer-to-peer consumer lending model is another debt-based model of crowdfunding, which accounted for over $£ 547$ million worth of loans in the UK in

\begin{tabular}{|l|l|l|l|}
\hline $\begin{array}{l}\text { Figure.2 Crowdfunding Model } \\
\text { in Numbers }\end{array}$ & $\begin{array}{l}\text { Average } \\
\text { Amount } \\
\text { Raised }\end{array}$ & $\begin{array}{l}\text { Average Number } \\
\text { of Funders }\end{array}$ & $\begin{array}{l}\text { Average } \\
\text { Contribution } \\
\text { Amount }\end{array}$ \\
\hline Debt-based Securities & $£ 730,000$ & 587 & $£ 1,243.61$ \\
\hline Equity-based Crowdfunding & $£ 199,095$ & 125 & $£ 1,592.76$ \\
\hline Community Shares & $£ 174,286$ & 474 & $£ 367.69$ \\
\hline Peer-to-Peer Business Lending & $£ 73,222$ & 796 & $£ 91.99$ \\
\hline Invoice Trading & $£ 56,075$ & 7 & $£ 8,010.71$ \\
\hline Donation-based Crowdfunding & $£ 6,102$ & 55 & $£ 110.95$ \\
\hline Peer-to-Peer Consumer Lending & $£ 5,471$ & 201 & $£ 27.22$ \\
\hline Reward-based Crowdfunding & $£ 3,766$ & 77 & $£ 48.91$ \\
\hline
\end{tabular}

2014. This crowdfunding model is growing rapidly; however, at this point, peer-to-peer consumer lending only represents $2 \%$ of the $£ 26$ billion worth of personal unsecured loans made in the UK in 2014 (Nostrum, 2015). Like its business counterpart, peer-to-peer consumer lending is a model where individuals borrow money from an amalgamated lender, comprized of hundreds of individual micro-loans, thus spreading the risk of lending over a 
large number of lenders. Similar to the traditional bank lending models, borrowers used the loan to purchase cars (46\%), fund home improvements (26\%) and to consolidate existing debt (25\%). However, sole traders and small firms also used the consumer loans to start or finance micro-businesses (3\%). Thus, the distinction between consumer and business lending on these peer-to-peer platforms can be overdrawn. Crucially, a number of peer-to-peer consumer platforms are now seeing substantial volumes of unsecured lending to these businesses.

The crowdfunding platforms function as intermediaries in peer-to-peer consumer lending. The platforms, in an increasingly automated fashion, reject or accept applications for unsecured loans from borrowers. Studies find rejection rates as high as $90 \%$ as the platform algorithms weed out all but the lowest risk borrowers with the highest credit scores (Zhang et al., 2014:40). Clearly, this does not function as a lending model for the economically marginalized. Conversely, the majority of successful borrowers had other offers of loans from the mainstream financial industry. The result is a very low default rate of less than $1 \%$ for the crowdfunding platforms that provide peer-to-peer consumer lending (ibid).

Lenders and borrowers are not only attracted by competitive interest rates than that offered by the traditional banks, but are also motivated by a pronounced anti-bank sentiment. Reflecting the continued resentment some respondents felt about the banking crisis of $2007 / 08$ and its lasting effect on public finances, many respondents wrote comments in their survey expressing anger and frustration with the banks. Unsolicited comments, such as "deliberately taking my business away from the big banks" and "supporting a real alternative to the traditional finance sector" were volunteered in a significant proportion of survey returns. Again, this suggests that, for some, the peer-to-peer consumer lending platforms offer an alternative financial mechanism worth pursuing for symbolic as well as financial reasons.

However, it remains very unclear the extent to which we can consider these peer-to-peer models as alternatives to traditional financial sources, as their success attracts major financial players. The crowdfunding industry has seen an influx of institutional funding from traditional financial institutions, such as pension funds, hedge funds, mutual funds, and asset management firms either lending through or buying equity stakes in crowdfunding platforms. In addition, governmental and non-governmental organizations such as the British Business Bank and county councils are investing through platforms as lenders, particularly in peer-topeer business lending, thus blurring the boundaries of traditional and alternative finance.

The other rapidly growing type of crowdfunding is equity-based crowdfunding, which is based on buying equity shares in early stage start-up or growth-stage firms. This model entails selling registered securities to investors (retail, professional, and institutional) and is often promoted as a type of "democratized" version of venture capital (Mollick, 2014; Schwienbacher and Larralde, 2010). The majority of our respondents ( $62 \%$ of the 290 investors) identified themselves as retail investors, with no previous experience of investing. This type of crowdfunding seems to attract investors with no pre-existing social ties, but also functions to formalize the financial support of friends and family. The rest, roughly $38 \%$, 
were either wealthy individuals or institutional investors. These investors were professional investors with previous experience investing in early stage firms or high net worth individuals.

In 2014, this equity-based crowdfunding model accounted for over $£ 84$ million worth of capital for small firms in the UK. To give this context, this compares to $£ 874$ million of total seed stage and venture stage equity investment in the UK according to Beauhurst (2015). As shown in Figure 2, the average equity fundraising deal on the crowdfunding platforms are much bigger than the average peer-to-peer business loan at $£ 199,095$. Typically speaking, around 125 investors would invest in a typical equity crowdfunding offering with $£ 1,592$ being the average investment amount per investor.

Although the platforms perform a number of "due diligence" procedures on the fundraising firms, this model is inevitably riskier than the debt-based models mentioned above, as the rate of failure for new ventures is high. These investors are often long-term investors, or "patient capital", as there is not always a secondary market for these shares and 'exits' (either through IPO or merger and acquisition) are hard to come by. This makes it impossible at this point to measure any return on investment at an aggregate level given there are only two known 'exists' in the UK thus far. From the fundraisers' perspective in our research, it seems that, besides funding, they also value the non-financial benefits associated with the crowdfunding process, such as marketing, branding, product testing, concept validation and user engagement.

Like the peer-to-peer business models, there is a large and growing segment of the equitybased model exclusively focused on the property industry. Equity-based crowdfunding for real estate enables investors to obtain ownership of a property by purchasing shares of a single property or a portfolio of properties through a special purpose vehicle (SPV). The risk of investing in real estate crowdfunding is typically lower than in pure equity-based crowdfunding with properties acting as collaterals for securities. However, the potential upside of investment could be smaller as well.

Crucially, the equity model of crowdfunding is heavily promoted by the state in the UK, who have created specific schemes to encourage investment in start-up firms. In particular, the great majority of the funded equity-based crowdfunding investments $(90 \%)$ were eligible for large income tax concessions through either the Enterprise Investment Scheme (EIS) or the Seed Enterprise Investment Scheme (SEIS). By allowing large tax deductions, these government schemes function to reduce risk for investors and encourage venture investing through crowdfunding.

Reward-based crowdfunding, although often perceived as being synonymous with crowdfunding itself, is actually very small in comparison with equity-based crowdfunding. In the UK, this model only reached $£ 26$ million in 2014 . Reward-based crowdfunding is a model in which individuals donate towards a specific project or firm with the expectation of receiving a tangible, but non-financial, return or reward for their support. As Figure 2 shows, reward-based crowdfunding has the smallest average fundraising amount at just $£ 3,766$,

Comment [JP2]: Perhaps some sub-headings in this section to make the navigation a bit clearer? 
which is typically funded by 77 backers each with a donation of $£ 49$. Akin to equity-based crowdfunding, in addition to providing funding, this model can enable fundraisers (particularly within the creative industries) to test their ideas, obtain a proof of concept, engage with their users and supporters as well as aid marketing efforts.

In the beginning of its development, reward-based crowdfunding was often employed as a fundraising alternative for unestablished artists, budding entrepreneurs, independent movie makers and unsigned singers and dancers. However, this model has also seen the introduction of large institutional players. In recent years, big brands and corporations, from Sony, Microsoft, AXA to Ben \& Jerry's, are leveraging the reward-based crowdfunding channels not to raise funds, but to test their products, create "social buzz" and engage with their consumers.

Donation-based crowdfunding is another small segment of the total crowdfunding phenomena, comprising less than $1 \%$ of the total volume. Unlike the reward crowdfunding model, donors in donation-based crowdfunding do not expect any returns - financial or nonfinancial. They are typically making contributions to support charities or good causes. The historical antecedent here comes from the traditional charity sector rather than a segment of the finance industry. According to our data, a typical donor will donate on average $£ 111$ on the crowdfunding platforms and it takes 55 donors to fund a donation-based crowdfunding campaign.

Invoice trading is another crowdfunding model that has emerged in the UK, which allows firms to quickly raise capital without resorting to either debt or equity. Invoice trading enables firms, which are mostly SMEs, to sell their invoices at a discount, in return for immediate working capital. This model accounts for $£ 270$ million in 2014 , thus accounting for around $16 \%$ of total crowdfunding market volume. Firms using invoicing trading are attracted by the speed of raising capital, which averaged only few hours in an on-line auction of invoices. The average firm using this model to raise funds was small, at less than 50 employees, and raised an average of $£ 56,075$. This particularly model functions to test the boundaries of 'crowdfunding' as, again, the large institutional investors dominate this form of capital formation. It is mostly institutional investors who are funding the auction of invoices rather than "a crowd" of smaller retail investors. On average, this model only takes seven institutional investors or high net worth individuals to finance a typical invoice.

The main reason firms gave for using invoice trading was to improve cash flow - cited by an overwhelming $92 \%$ of respondents. Unlike the peer-to-peer business model, the majority of these firms had approached the traditional banking sector first and $80 \%$ of those firms had been turned down by the banks. Thus, the speed and flexibility of invoice trading made it a useful funding mechanism for small firms.

In contrast, one of the most locally-oriented types of crowdfunding is the community-based model. In this model, individuals invest in a withdrawable share of a community project. The projects range from renovating a village hall, to creating renewable energy projects, to major construction projects for a new arts centre. In 2014, this crowdfunding model raised roughly 
$£ 34$ million in the UK. This is perhaps the model that best fits a democratized model of funding. The funding model is based on UK legislation from the cooperative and community benefit societies. Funders' investments are amalgamated to support the community project, and supporters choose which individual projects to support. In 2014, successfully funded community projects combined funds from an average of 474 investors, each investing an average of $£ 368$.

The majority (55\%) of community supporters chose a local project which they are able to access themselves. Some revenue-generating community projects have the potential of repaying the supporters if they wish to cash in their shares, although many funders are motivated by "investing in my local community" (89\%) rather than "financial returns" (24\%). Perhaps, in a reflection of this, funders in this model also often became personally involved in the running and monitoring of the community project. A sizeable proportion of funders thought it was important to get directly involved with the project (33\%), and to attend shareholders' meeting and AGMs (37\%), as well as to get their investment back (30\%). Overall, the community-based model of crowdfunding allows social, community, and environmentally-oriented investing to flourish.

Finally, the debt-based securities sector is a niche section of the crowdfunding market, which only recorded $£ 4 \mathrm{~m}$ in total volume in 2014 . However, as demonstrated by Figure 2, a typical crowdfunding campaign in this model on average raises over $£ 730,000$ from 587 investors. The large sum of investment is a reflection of its market function, which is to provide longterm 'patient capital' for relatively large-scale renewable energy projects in the UK such as wind farms and solar panel installation. The debt-based securities, such as bonds and debentures, are issued by renewable energy companies with a fixed majority and interest rate. Most debt-based securities issued, unlike that of the community shares, are fully tradable and transferrable. This crowdfunding model taps into investors' social and environmental affinity to renewable energy and offers long-term investment opportunities which can have 20 or 25year maturity, far longer than the 3-5 year loan terms offered by peer-to-peer business lending platforms.

This section introduced an array of distinctive models of crowdfunding. We argue that it is vital to delineate each model to understand their differing market sizes, highly differentiated funding mechanisms, composition of investors, fundraising dynamics and funding outcomes. It is evident that crowdfunding is an ambiguous and often convoluted umbrella term which lacks conceptual and empirical clarity. It includes an array of financial flows including charitable giving, for-profit, lending, high risk seed-capital investing, and community building. To conduct a critical and in-depth analysis of crowdfunding, one must adopt a more nuanced approach in order to appreciate the characteristics of these highly diverse models. 


\section{Diversity in Geography}

In the UK, the concentration of the financial services industry in London and the South East and the centralization of its financial power has long been a hallmark of the institutional geography of traditional finance (Klagge and Martin, 2005). This concentrated and centralized geography of finance is pronounced both in regard to SME financing (Martin, 1999) and venture capital financing (Mason and Harrison, 2002; Martin et al., 2003), with resulting locational biases, often against the SMEs and start-ups in the areas and regions outside London and the South East. Therefore, it is pertinent to examine whether the economic geography of crowdfunding, which facilitates funding through online alternative channels (i.e. platforms), exhibits different kinds of geography, both in terms of funding (where the money comes from), fundraising (where the money goes) and the regional patterns of flow (whether a region has a higher or lower proportion of fundraisers in relation to funders). More importantly, will different crowdfunding models demonstrate varied or even contrasting spatial patterns?

In this section, we investigate the geography of funding and fundraising for the four most prevalent crowdfunding models in the UK. They are peer-to-peer business lending, peer-topeer consumer lending, and equity- and reward-based crowdfunding. Combined together, these four models account for over $80 \%$ of the total crowdfunding market volume in the UK. As discussed above, peer-to-peer business and consumer lending are debt-based crowdfunding, whilst equity-based crowdfunding relies upon the sales of securities or shares and reward-based crowdfunding facilitates donations from backers for tangible, but nonfinancial, returns.

For peer-to-peer consumer lending, where consumers borrow money from other individuals through highly-automated online platforms, the survey findings depict a 'decentralised' geography of crowdfunding with more funding outflow from London and the South East (the centre) to the rest of the regions in the UK. As Figure 3 demonstrates, based on over 10,000 survey responses, it seems that there are higher proportions (as \% of surveyed sample) of lenders than borrowers in London and the South East when compared to the rest of the UK regions. Nearly $15 \%$ of the surveyed lenders and $8 \%$ of surveyed borrowers in peer-to-peer consumer lending are based in London, while $22 \%$ of surveyed lenders and $17 \%$ of surveyed borrowers are from the South East. Furthermore, 7\% of the surveyed lenders and 5\% of surveyed borrowers are from the East of England. We assume that the average lending amount per lender and borrowing amount per borrower do not vary significantly across regions (as validated by our granular-level transaction dataset). Given this, our findings suggest a spatial outflow of funding from London and the South East to the rest of the UK regions. London seems to be the biggest net exporter of funding ( $7 \%$ difference between the surveyed lenders and borrowers), follow by the South East (5\%) and the East of England $(2 \%)$. This, in turn, depicts a 'decentralising' geography for the peer-to-peer consumer lending model of crowdfunding. Indeed, in most of the regions outside of London and the South East, there is a higher percentage of surveyed borrowers than lenders. For instance, in Scotland, there are 5\% more surveyed borrowers than lenders; in the North West, the difference is $4 \%$, whilst the gap is $2 \%$ in the North East and Northern Ireland regions. 


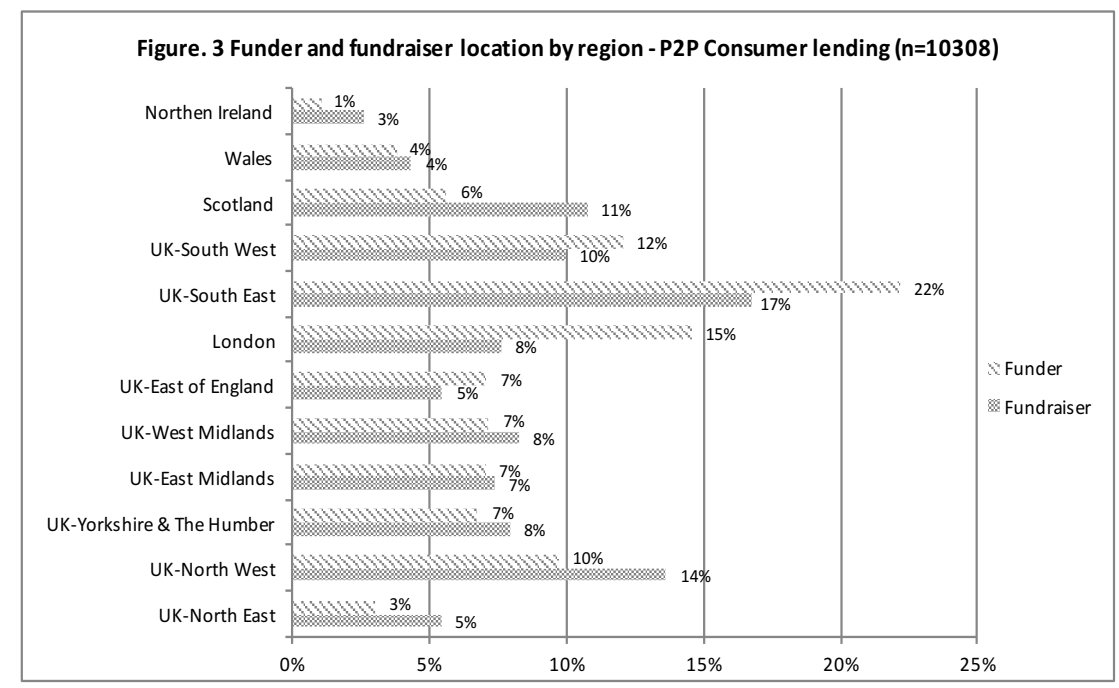

Our survey data from 1,654 lenders and borrowers of peer-to-peer business lending also depicts a decentralized geography of crowdfunding, albeit to a smaller degree. As illustrated in Figure 4, there are 2\% more surveyed lenders than surveyed SME borrowers in London. In the South East, the gap is 1\%, while in the East of England the difference is $6 \%$, with $9 \%$ of all surveyed funders for peer-to-peer business lending being located in this region in contrast to $3 \%$ of surveyed SME borrowers. Again, assuming the average lending amount per funder and borrowing amount per fundraiser do not vary significantly across regions, which is supported by our transactional dataset, it seems that London, the South East and the East of England are all net exporters of funding in online peer-to-peer business lending. In contrast, the percentage of surveyed SME borrowers seems to be higher than the percentage of surveyed lenders in the West Midlands (5\% difference), North West (3\%), East Midlands $(2 \%)$, Wales (2\%), Northern Ireland (1\%) and North East (1\%), indicating a net inflow of funding for SMEs through peer-to-peer business lending online channels for these regions. Although the regional pattern differences are less pronounced in peer-to-peer business lending than in peer-to-peer consumer lending, the findings still illustrate a decentralizing geography of debt-based crowdfunding, where funding is flowing disproportionately from London and the South East to the rest of the UK. This is very different to the centralized geography of traditional finance, where London and the South East are usually attracting disproportionately higher levels of funding than the rest of the UK. 


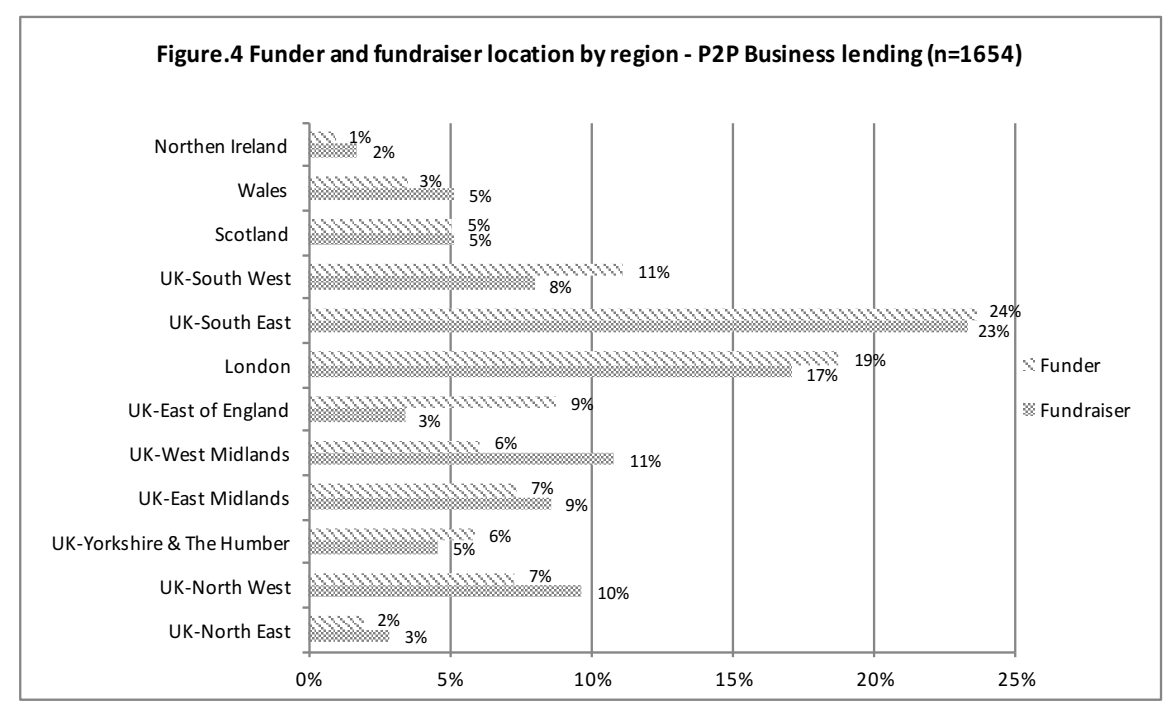

However, other models of crowdfunding show a very different geography. Equity- and reward-based crowdfunding show signs of the centralization of funding, which closely resemble those of traditional venture finance. Clearly, London still dominates equity-based crowdfunding, which facilitates mostly seed-stage and early-stage venture capital for startups, with $41 \%$ of surveyed fundraisers/entrepreneurs and $31 \%$ of surveyed investors located in the region (Figure 5). Assuming the average equity investment amount per investor (i.e. averaging £1,592) and the fundraising amount per fundraiser (i.e. averaging £199,095) do not vary significantly between regions, London benefits from being the main 'net importer' of venture capital funding channelled through equity-based crowdfunding platforms in the UK. Many other UK regions are the 'net exporters' in this particular crowdfunding model, with the South East ( $8 \%$ difference between the percentage of investors and fundraisers), Wales (4\%), Yorkshire and the Humber (3\%), the East of England (1\%) and the North East (1\%) all seemingly contributing net outflow of funding to London. Nevertheless, it is worth noting that both Northern Ireland and the South West regions have a higher percentage of fundraisers than the percentage of investors in equity-based crowdfunding, which indicate a net inflow of funding from equity-based crowdfunding. In the case of the South West, it has $15 \%$ of surveyed fundraisers and $12 \%$ of surveyed investors in the survey sample.

Correspondingly, the South West also has a disproportionately higher level of funding volumes and number of equity-based crowdfunding deals which originated in the region, according to our transactional dataset. This could be explained by the fact that one of the largest and most successful equity-based crowdfunding platforms in the country is based in the South West. Therefore, the region has benefited from this particular institutional 
geography anomaly accordingly with heightened equity-based crowdfunding activities and funding volume in the region. Nevertheless, overall, equity-based crowdfunding is exhibiting a centralized geography very similar to that which we have seen in the traditional venture capital paradigm, with London gaining a much higher proportion of funding than the rest of the UK regions.

In a similar vein, although reward-based crowdfunding has been applauded in the press and

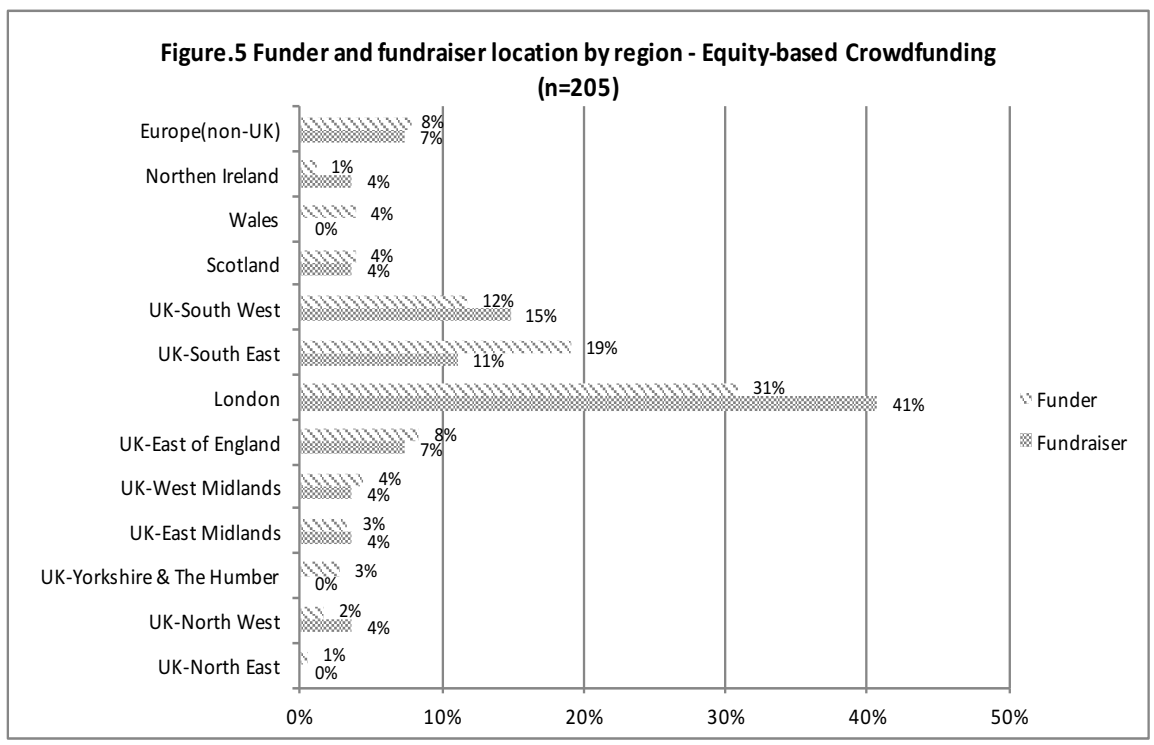

academic studies alike for its potential to 'democratize finance and make it more accessible' (Shiller, 2013), at least in terms of regional geography, it has failed to break the mould according to our survey data. Our findings show London is still the dominant region in the UK in this model, with $26 \%$ of surveyed fundraisers/campaign owners and $19 \%$ of surveyed funders/backers. Again, assuming average donation and fundraising amounts for rewardbased crowdfunding do not vary significantly between regions, London seems to be a 'net importer' of funding flows from the reward-based crowdfunding online channels. The South East is also prevalent, with $14 \%$ of surveyed fundraisers and $11 \%$ of surveyed funders. However, many other regions have a disproportionately higher percentage of surveyed funders than percentage of surveyed fundraisers, such as the South West (3\% difference), Wales (2\%), West Midlands (2\%) and North East (1\%), which indicate funding outflow. Interestingly, given the global nature of reward-based crowdfunding and the proliferation of international reward-based crowdfunding platforms such as Kickstarter, $9 \%$ of the surveyed funders and $6 \%$ of the surveyed fundraisers are actually from outside of the UK.

Notwithstanding the similarities to equity-based crowdfunding, our findings suggest that 
reward-based crowdfunding is demonstrating a more centralized geography akin to that of traditional finance.

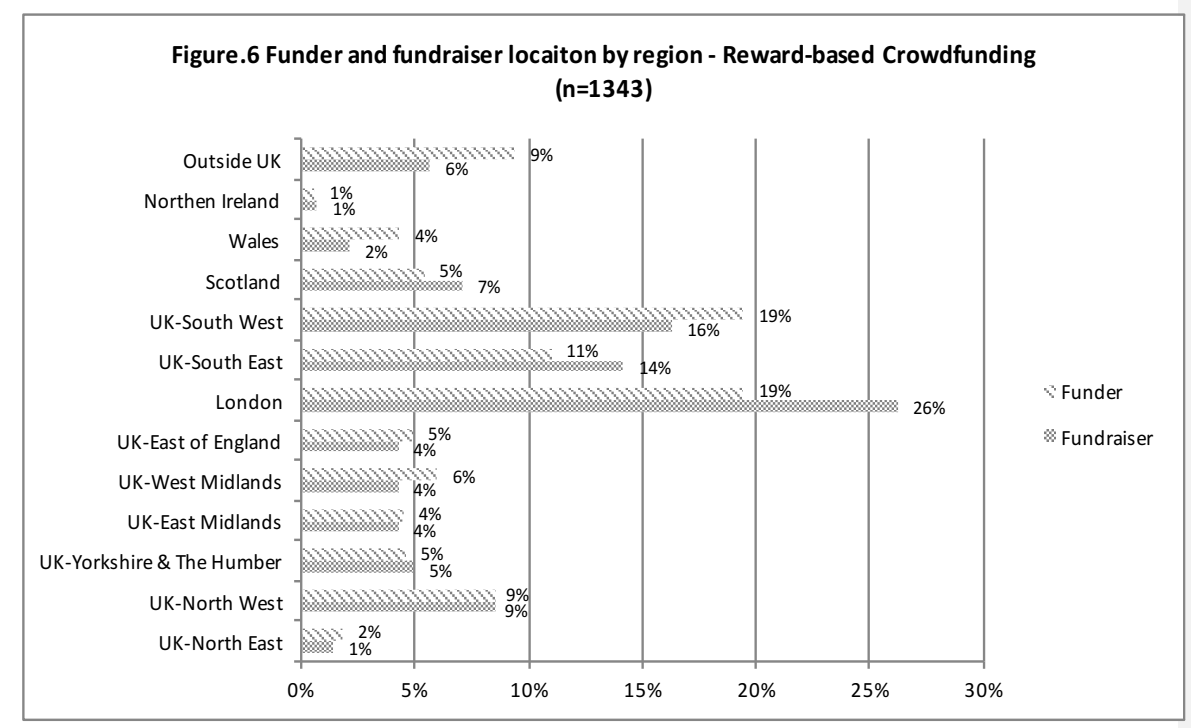

Overall, it seems that equity- and reward-based crowdfunding reinforce, if not exacerbate, the centralised geography of finance by channelling more funding inflow than outflow to London and the South East. In contrast, debt-based crowdfunding models, such as peer-to-peer consumer lending and business lending, exhibit a more decentralised geography of crowdfunding by channelling more funding inflow to the rest of UK regions from London and the South East. Therefore, when it comes to geographical and spatial analysis of crowdfunding, it is imperative to examine each distinctive crowdfunding model in detail and appreciate the extent to which they challenge or reinforce the geographies of investing and lending in the mainstream financial institutions.

\section{Diversity in the Crowd: Gender and Income}

One of the problems of the existing literature on crowdfunding is that people tend to treat 'crowd' as a homogenous entity without developing a more nuanced understanding of who comprises the crowd and their demographic and socio-economic characteristics. This applies to both funders, who are sources of funding and fundraisers, who are the recipients of funding. Furthermore, we need to examine whether the dynamics and composition of the 'crowd' vary from a crowdfunding model to a crowdfunding model in order to understand the socio-economic implications and impact of crowdfunded capital; for instance, on widening access to finance in terms of gender and income equality in comparison with the traditional finance paradigm. 
There are long-standing gendered patterns of funding in the traditional finance sector, which disadvantage female entrepreneurs (Brush et al., 2014; Marlow and Patton, 2005). We explored the extent to which these might be challenged or reversed by the different crowdfunding models. From this perspective, it is evident that female participation levels in fundraising through online crowdfunding channels, as an entrepreneur, a campaign owner or a borrower, are highly varied from model to model (Figure 7). At first, it seems striking that $64 \%$ of fundraisers in donation-based crowdfunding are women, far higher than that of any other crowdfunding models. This is probably not too surprising, however, considering around two-thirds (66\%) of the voluntary sector workforce are women in the UK (NCVO, 2014). Therefore, it is expected that a higher percentage of fundraisers in donation-based crowdfunding, which is primarily catering for charitable and voluntary sector fundraising, would be women. Reward-based crowdfunding has the second highest percentage of women fundraisers among all crowdfunding models at $51 \%$. This finding is interesting, as rewardbased crowdfunding is popularly utilized by fundraisers who are working in the digital and creative industries such as filmmaking, video games, design and fashion. According to the UK Commission for Employment and Skills, just one quarter (26\%) of the workforce in the digital and creative sector in the UK are female (UKCES, 2015). Reward-based crowdfunding seems to be offering more fundraising opportunities to women who work in the digital and creative industries.

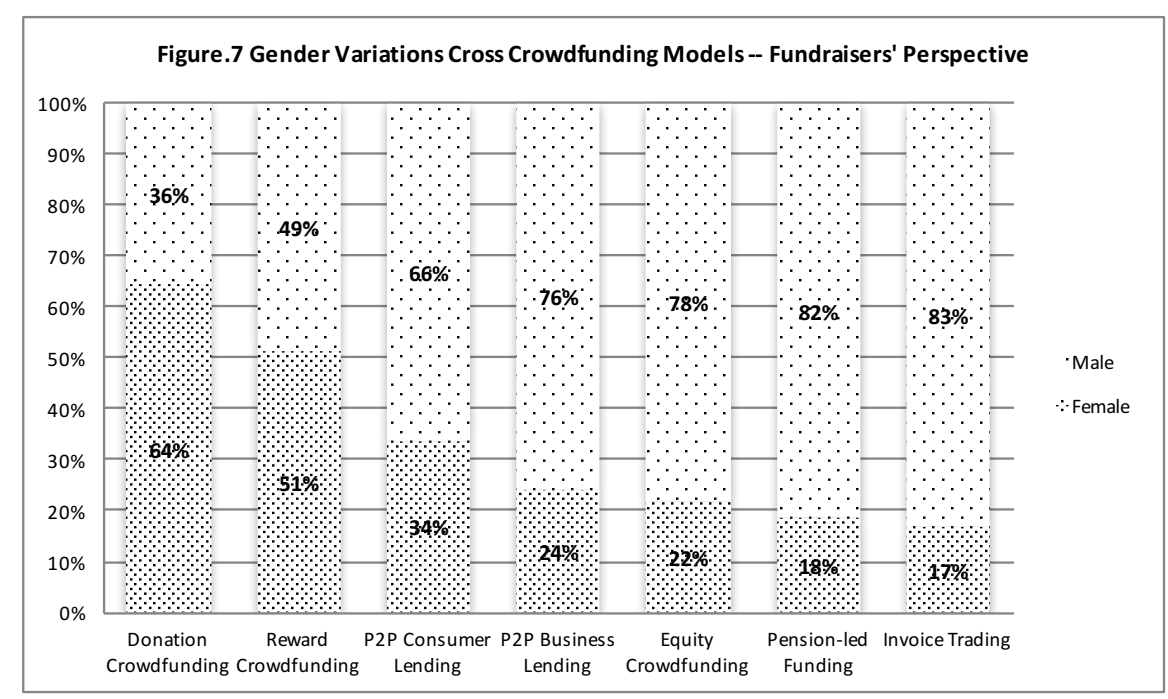

As discussed above, equity-based crowdfunding facilitates seed-stage and early-stage venture capital funding for entrepreneurs. Traditionally speaking, female entrepreneurs are less likely than men to acquire venture capital from either business angels or venture capitalists (Brush et al., 2014). During an extensive study, which surveyed 6,517 companies that received venture capital funding in the USA between 2011 and 2013, only $2.7 \%$ of the companies had 
a woman founder or CEO (ibid). In addition, women only make up a small percentage (1-3\%) of high-tech entrepreneurs, which is an active group vying for venture capital funding (Robb and Coleman, 2009). Our survey findings show that $22 \%$ of the fundraisers in equity-based crowdfunding in the UK are women, which seems to be significantly higher than statistics gathered under the traditional venture capital paradigm. The much higher percentage of female fundraisers in this model may indicate that they were unable to access funding through traditional financial institutions.

Access to credit from banks is one of the greatest and most prevalent challenges female entrepreneurs and borrowers face (Gatewood et al., 2004). Our survey findings show that $24 \%$ of business borrowers on peer-to-peer lending platforms are women. In addition, $17 \%$ of the SME borrowers who auction invoices or receivables on crowdfunding platforms are women. Our data also shows that $34 \%$ of consumer borrowers are women, some of which may be using consumer credit to finance activities as sole traders. Taken in total, this suggests that the different models of crowdfunding may function to open up alternative channels of finance for female owners of SMEs.

From the funders' perspective, there is also a significant variation in gender composition across crowdfunding platforms. Figure 8 illustrates that $17 \%$ of the lenders on peer-to-peer business lending platforms and $18 \%$ of investors on equity-based crowdfunding platforms are women. The percentage of female funders is higher in peer-to-peer consumer lending at $27 \%$ and reward-based crowdfunding at $42 \%$. These findings show that female participation in the crowdfunding market from the funding side is significant and varied across models. 
To investigate whether crowdfunding can truly 'democratize finance', it is also important to examine the income profiles of both funders and fundraisers. Our data shows significant

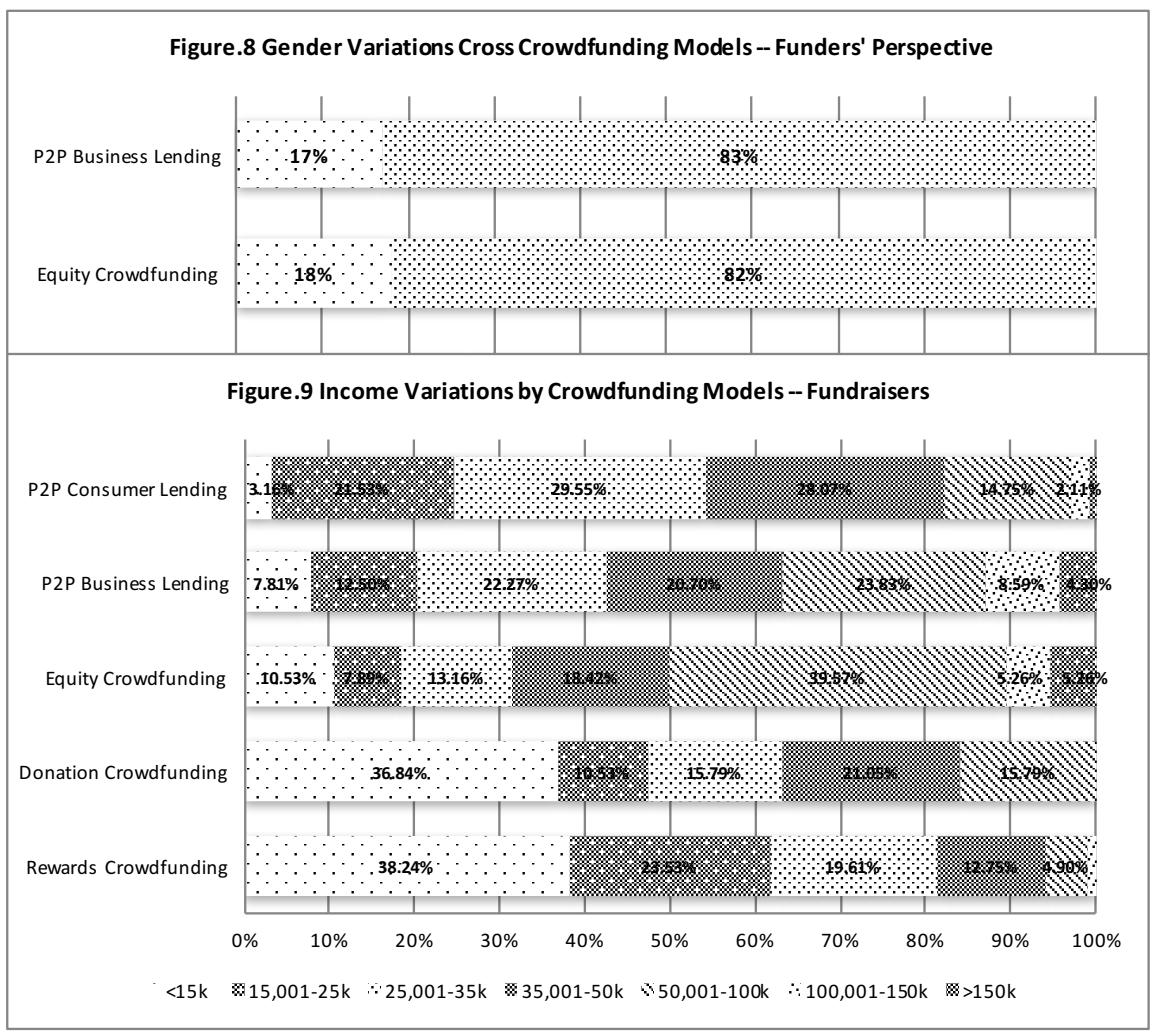

income variations among fundraisers across five prevalent crowdfunding models (Figure 9). It is striking that borrowers on peer-to-peer consumer lending platforms seem to be occupying the higher end of the income spectrum, with $46 \%$ of the borrowers earning more than $£ 35,000$ per year and $18 \%$ earning more than $£ 50,000$ per year. Around $3 \%$ of the borrowers on peer-to-peer consumer lending platforms are actually earning more than $£ 100,000$ per year, with only $25 \%$ of the borrowers earning less than $£ 25,000$ per year. These findings coincide with our earlier discussions that the vast majority of approved borrowers on peer-to-peer consumer lending platforms are relatively well-off people, who are either prime or super-prime borrowers with excellent credit ratings. Most of them can easily access credit and borrow money from the banks. The primary reasons for them to opt to borrow on peer-topeer lending platforms are 'better interest rates' ( $71 \%$ rated as a very important factor), 'more flexible terms' (56\%), 'ease of use' (52\%), 'transparency' (50\%), 'speed' (50\%), 'more control' (45\%) and 'better services' (42\%) (Zhang et al., 2014, 45). These results question that extent to which crowdfunding is "broadening and deepening" access to capital markets for ordinary individuals (Erturk et al., 2007). 
In a similar vein, significant numbers of SME owners who are borrowing on peer-to-peer business lending platforms and entrepreneurs who are fundraising on equity-based crowdfunding platforms also belong to the higher end of the income strata according to our survey data. A large proportion (37\%) of the SME borrowers on peer-to-peer business lending platforms are earning more than $£ 50,000$ per year. The pattern is similar for equitybased fundraisers. Just over $50 \%$ of the fundraisers on equity-based crowdfunding are also earning more than $£ 50,000$ a year, with $11 \%$ earning more than $£ 100,000$ a year. Only $19 \%$ of the fundraisers on equity-based crowdfunding platforms and $20 \%$ of borrowers on peer-topeer business lending platforms are earning less than $£ 25,000$ a year. Therefore, the data shows that these models of crowdfunding are serving a significant number of people who already have access to credit and have the ability to obtain capital from traditional channels, albeit more efficiently, speedily and on better terms.

However, when it comes to non-investment models such as donation- and reward-based crowdfunding, the income profiles of fundraisers do alter remarkably. For instance, $37 \%$ of the fundraisers on donation-based crowdfunding platforms have income levels lower than $£ 15,000$ per year. $63 \%$ of the surveyed fundraisers have annual earnings less than $£ 35,000$ and only $16 \%$ are earning more than $£ 50,000$ per year. Similarly, $39 \%$ of the fundraisers on reward-based crowdfunding platforms are earning less than $£ 15,000$ per year and $81 \%$ of the fundraisers are earning less than $£ 35,000$ a year. Therefore, we can also argue that particularly models of crowdfunding, such as donation- and reward-based crowdfunding, can function as effective and alternative capital accumulation channels for people who come from lower income backgrounds and who might have difficulty in raising capital or accessing credit through traditional means.

When it comes to funders, there are also important variations in the income profiles of investors, backers, lenders and borrowers (Figure 10). The backers and donors of reward- and donation-based crowdfunding seem to have relatively lower income levels. Roughly $66 \%$ of the backers for reward-based crowdfunding and $63 \%$ of the donors for donation-based crowdfunding are earning less than $£ 35,000$. This seems to support the thesis that people from the lower income groups tend to donate disproportionately more than well-off people (NewTithing Group, 2004). On the other end of the spectrum, the investors for equity-based

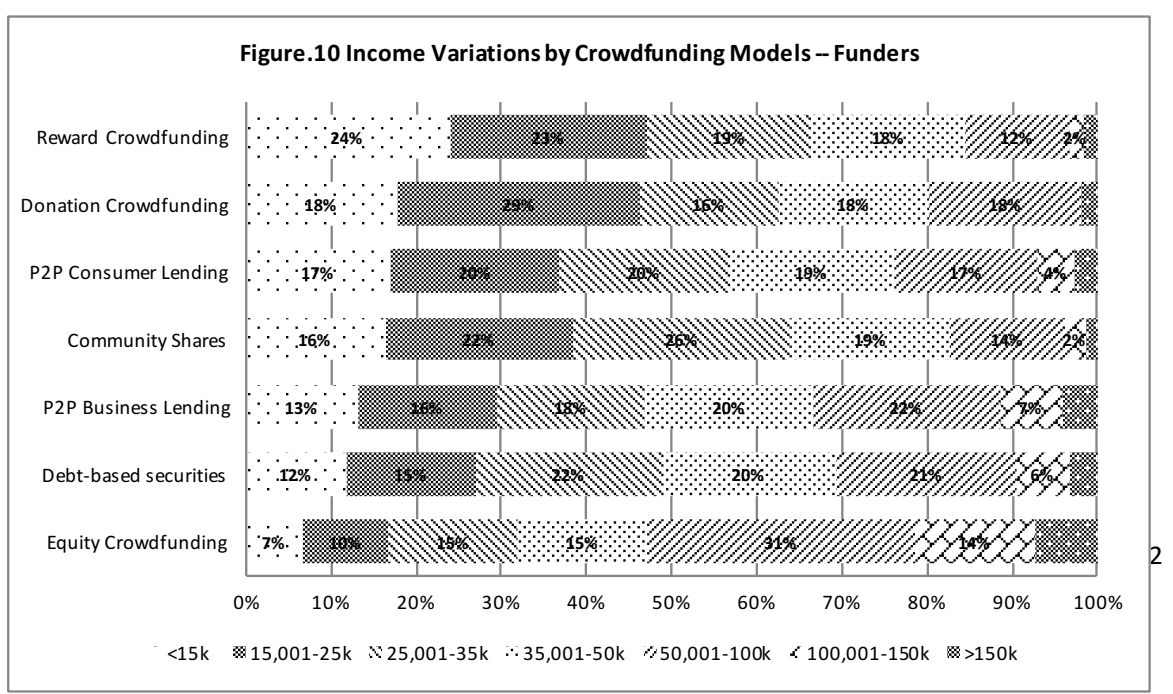


crowdfunding seem to be more well-off, with only $32 \%$ of them earning less than $£ 35,000$ per year. The majority of investors (53\%) on equity-based crowdfunding earn more than $£ 50,000$ per year, with $21 \%$ of them earning more than $£ 100,000$. If angel investing and venture investing have always been a more privileged financial activity for the rich and welloff, equity-based crowdfunding's investor base doesn't seem to be a radical departure from that paradigm.

Nevertheless, it is also interesting to note that, for the other two prevailing investment crowdfunding models - peer-to-peer consumer and business lending - a significant number of lenders/funders have an annual income of less than $£ 35,000$. In fact, $57 \%$ of the lenders in peer-to-peer consumer lending are earning less than $£ 35,000$ per year, with $17 \%$ reported earning less than $£ 15,000$ per year. Similarly, $47 \%$ of the lenders in peer-to-peer business lending are earning less than $£ 35,000$ annually, with $13 \%$ reported earning less than $£ 15,000$ per year. From our qualitative studies, it was apparent that, although some of these lenders do come from lower income groups and intend to invest a small amount of money (e.g. £20-£50) to test the water with peer-to-peer lending and 'taking a punt', a significant proportion of the lenders are 'cash-poor' but 'asset-rich' pensioners over the age of 65 . In this sense, from the funding side at least, some crowdfunding models such as peer-to-peer lending do offer new opportunities and access to new asset classes (e.g. peer-to-peer loans) for people who are normally not involved in, or able to participate in, these investment marketplaces. Therefore, to have a detailed and nuanced analysis about crowdfunding, one needs to be aware of the diverse income and gender profiles associated with each of the distinctive crowdfunding models.

\section{Diversity in Funding and Fundraising Motivations}

To begin to understand if crowdfunding offers an alternative circuit of finance, which allows capital to be accumulated and distributed differently to traditional finance, either socially or economically, we need to examine the motivations for both funders and fundraisers to use crowdfunding.

Community shares, debt-based securities, equity-based crowdfunding and peer-to-peer business lending are all forms of investment crowdfunding where investors or lenders are expecting financial returns for their capital. However, as the data in Figure.11 clearly demonstrates, financial motivation is a much more important factor in some of the crowdfunding models than in others. The overwhelming majority of investors and lenders in equity-based crowdfunding and peer-to-peer business lending state that 'making a financial return' is a very important motivational factor for them to invest through crowdfunding platforms. Indeed, $99 \%$ of the surveyed lenders in peer-to-peer business lending rate 'making a financial return' as either a very important or important factor. Similarly, $95 \%$ of the investors in equity-based crowdfunding made the same claim. However, for investors in community shares and debt-based securities, only $3.5 \%$ and $22 \%$ of them rated 'making a financial return' as a 'very important' motivational driver for making investments. Indeed, in 
community shares, only $23 \%$ of the investors think making a financial return is either very important or important. Some $39 \%$ of the total surveyed investors regard making a financial return as either 'unimportant' or 'very unimportant'.

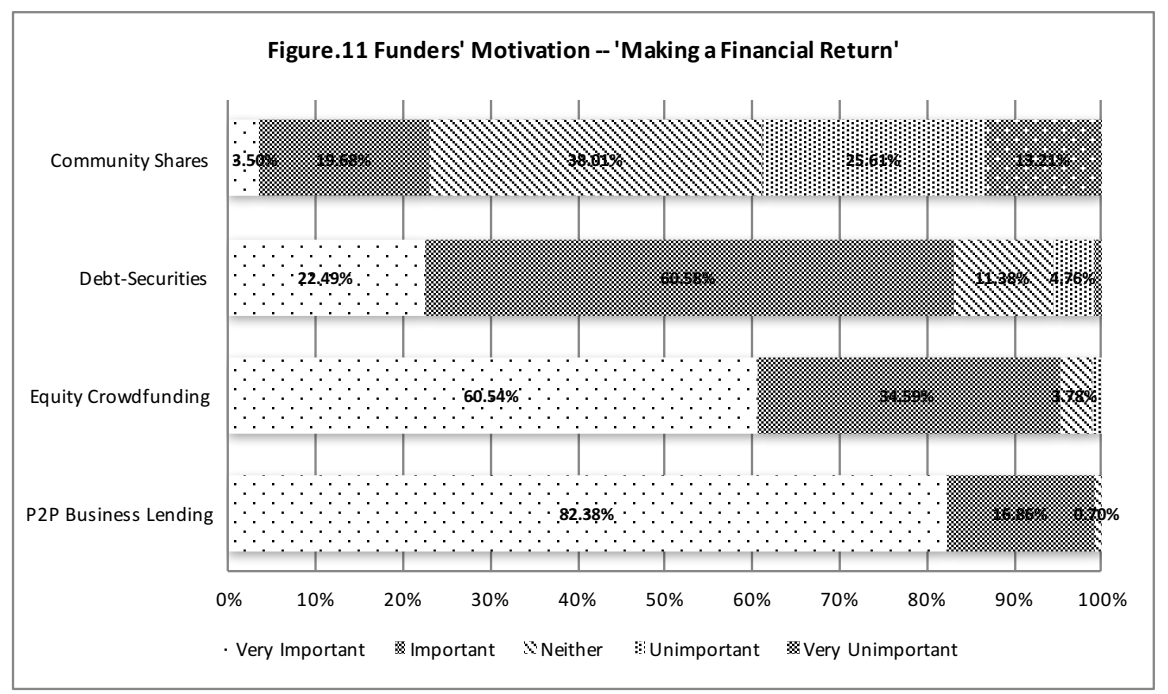

This discrepancy in funders' motivation across crowdfunding models is further validated and, at least partially, explained by Figure 12, which depicts the perceived importance of 'doing social and environmental good' as a motivational factor for investing in some models of crowdfunding. Unsurprisingly, given the importance of making a financial return, investors and lenders in peer-to-peer business lending and equity-based crowdfunding give relatively low importance to this factor. Only $7 \%$ of the lenders and $10 \%$ of the investors in these two crowdfunding models state that doing social and environmental good is a 'very important' factor in their decision to invest in crowdfunded loans or start-ups. In contrast, $44 \%$ of the lenders in debt-based securities and $53 \%$ of the investors in community shares claim that

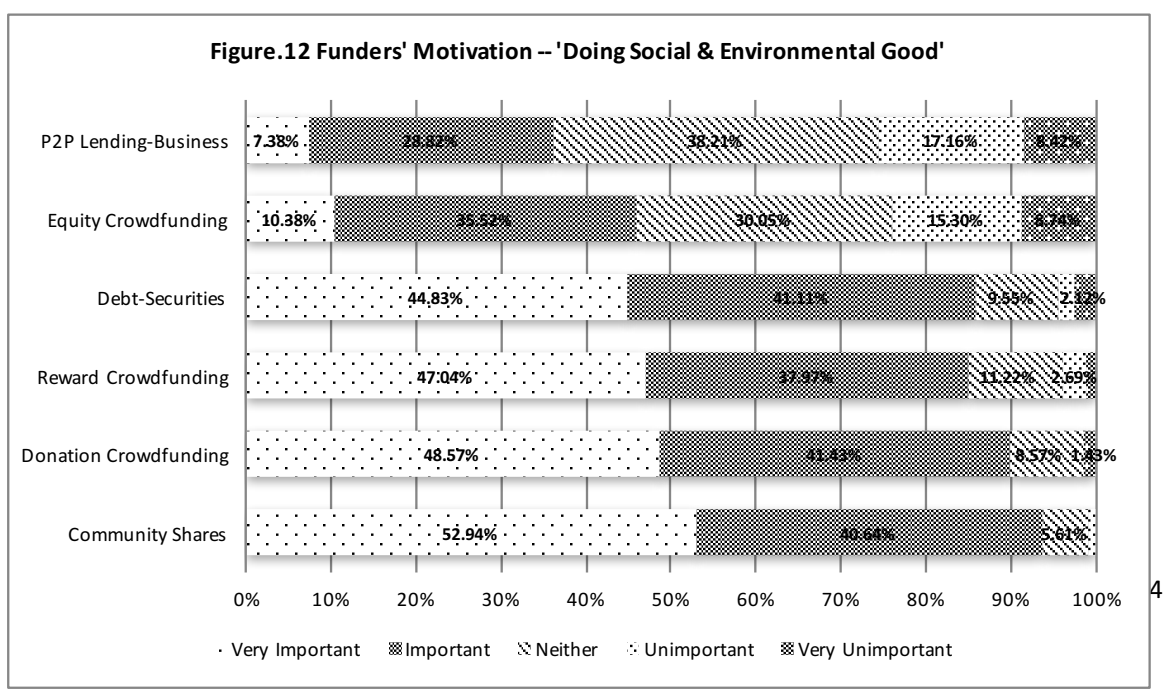


'doing social and environmental good' is a very important factor for them, definitely more so than 'making a financial return'. Backers and donors in reward- and donation-based

crowdfunding also exhibited a higher level of affinity with 'doing social and environmental good'. 
From the fundraiser's perspective, our data illustrates the variations in perceived importance of 'unable to source funding locally' as a motivational factor for crowdfunding. For both equity-based crowdfunding and peer-to-peer business lending, there seem to be a real challenge for fundraisers to raise capital locally (Figure.13). We find $59 \%$ of the SME borrowers in peer-to-peer business lending and $66 \%$ of the entrepreneurs in equity-based crowdfunding state that 'unable to source funding locally' is either a 'very important' or 'important' determining factor for them to choose raising capital through crowdfunding.

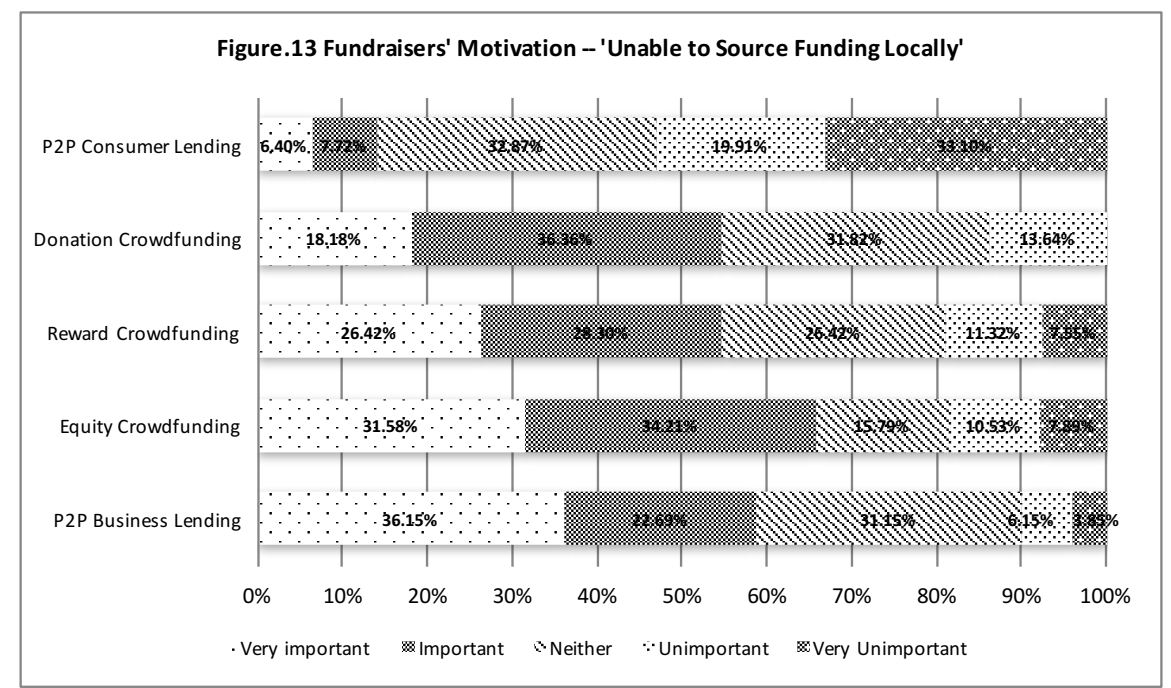


From our qualitative research, it seems that 'unable to source funding locally' can either imply difficulties in fundraising in a particular locality (e.g. raising venture capital in

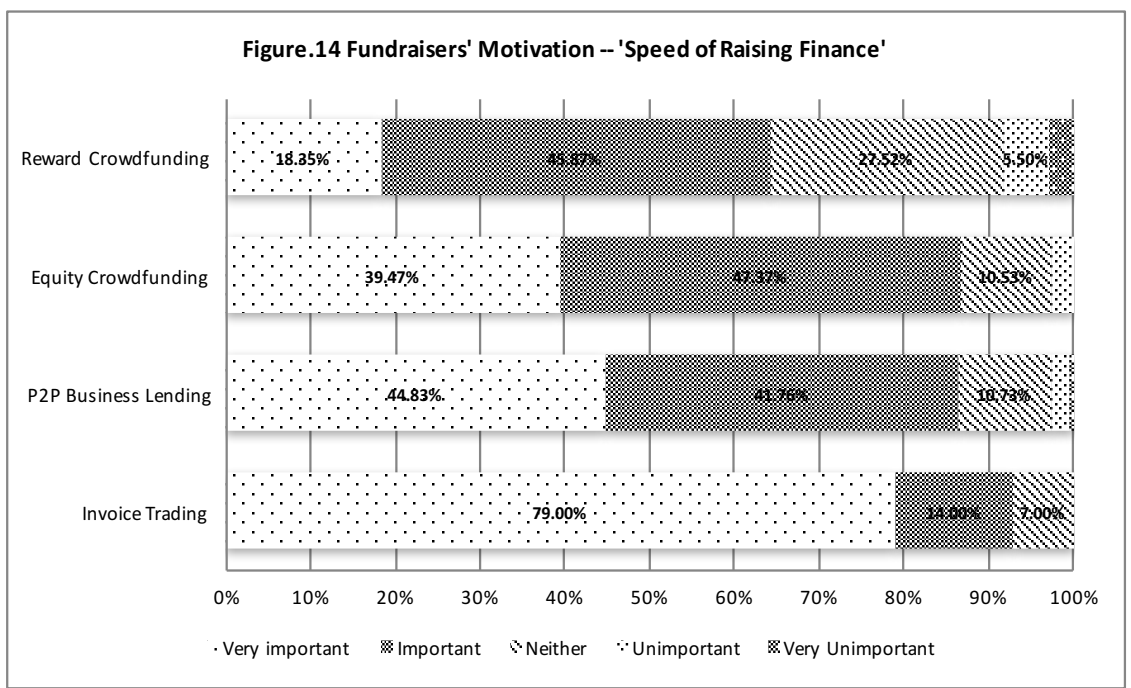

Newcastle) or through traditional financing channels (e.g. a consumer product start-up raising angel investment in London). Around $55 \%$ of the fundraisers in reward- and donation-based crowdfunding also cited this factor as either important or very important. However, it is interesting to note that only $6 \%$ of the borrowers in peer-to-peer consumer lending feel 'unable to source funding locally' is a key motivational factor. This correlates with and further validates our previous observation, that borrowers in peer-to-peer consumer lending are mostly well-off individuals with excellent credit ratings and have no great difficulties in accessing bank credit. Speed of funding is another important motivation for fundraisers in various crowdfunding models (Figure 14). Clearly, for most of the models, the "speed of raising finance" was an important factor offered by crowdfunding when compared to traditional channels of finance. Around $85-90 \%$ of fundraisers in most of the crowdfunding models consider it either 'very important' or 'important' as a motivational factor. It is worth noting that this factor was less an issue for fundraisers in reward-based crowdfunding (only $18 \%$ of them rating it as a 'very important' factor).

Finally, as mentioned earlier, the 2008 banking crisis, the mis-selling of financial products, and corrupt practices in some high-profile banking houses have also clearly affected the motivations of some users of the peer-to-peer lending models. Although our survey did not include a question on borrowers' and lenders' attitudes towards the mainstream finance industry, a significant proportion of respondents in the peer-to-peer crowdfunding models wrote comments on the survey which indicated a pronounced anti-bank sentiment. The 
comments suggested respondents consciously used peer-to-peer models as an alternative form of finance in order to sidestep the traditional banking system.

This analysis of the varied motivations of crowdfunding users highlights the importance of developing a nuanced understanding of different models. Financial motivation is clearly pronounced in the equity-based and business-lending models, while promoting social and environmental good motivates users in many other models. Avoiding mainstream financial institutions seems to motivate others - particularly in the peer-to-peer lending models.

\section{Towards a Working Taxonomy for Crowdfunding}

Our data and analysis have shown that it is imperative to distinguish various crowdfunding models and to examine them systematically and critically in academic studies. Crowdfunding is not homogeneous, but rather a spectrum consisting of highly differentiated models exhibiting an array of social, economic and geographical characteristics. Some of the models are akin to charitable giving, others function like venture capital; the gender and income profiles of fundraisers in peer-to-peer consumer lending is very distinct to that of the rewardbased crowdfunding; funders are motivated differently in community shares than in peer-topeer business lending. We should be wary of any academic claim that conflates these distinct models or discusses them all in the same breath.

Thus, it is useful to develop a clearly defined taxonomy of prevalent crowdfunding models to aid further academic studies. Our working taxonomy (Table 2) below has been gradually developed and refined in the last three years from both academic and industry research (e.g. Zhang et al., 2013). It encompasses the eight models of crowdfunding models we have explored in this chapter, which are defined in a simple language and with suggestions for appropriate terms to describe 'funders' and 'fundraisers' in each model. This taxonomy is meant to be a work in progress and, of course, will evolve with the development of the industry and the progress of the academic studies associated with it. It is by no means an end product, but a method by which to begin our understanding of a growing phenomenon and to crystallize our conceptualization of this fluid landscape.

\begin{tabular}{|l|l|l|}
\hline $\begin{array}{l}\text { Crowdfunding } \\
\text { Model }\end{array}$ & Definition & $\begin{array}{l}\text { Terms to describe those } \\
\text { who provide funding } \\
\text { and receive funding }\end{array}$ \\
\hline $\begin{array}{l}\text { Peer-to-Peer } \\
\text { Business Lending }\end{array}$ & $\begin{array}{l}\text { Secured and unsecured debt-based } \\
\text { transactions between individuals/institutions } \\
\text { and SMEs with trading history. }\end{array}$ & Lenders and Borrowers \\
\hline $\begin{array}{l}\text { Peer-to-Peer } \\
\text { Consumer Lending }\end{array}$ & $\begin{array}{l}\text { Mostly unsecured debt-based transactions } \\
\text { between individuals/institutions to a } \\
\text { consumer borrower. }\end{array}$ & Lenders and Borrowers \\
\hline
\end{tabular}




\begin{tabular}{|c|c|c|}
\hline Invoice trading & $\begin{array}{l}\text { Businesses sell their invoices or receivables } \\
\text { to a pool of primarily high-net-worth } \\
\text { individuals or institutional investors at } \\
\text { discount. }\end{array}$ & $\begin{array}{l}\text { Investors and } \\
\text { Borrowers }\end{array}$ \\
\hline $\begin{array}{l}\text { Equity-based } \\
\text { Crowdfunding }\end{array}$ & $\begin{array}{l}\text { Sale of registered securities, by mostly start- } \\
\text { ups or early-stage firms, to both retail, } \\
\text { sophisticated and institutional investors (e.g. } \\
\text { VCs). }\end{array}$ & $\begin{array}{l}\text { Investors and } \\
\text { Fundraisers }\end{array}$ \\
\hline Community Shares & $\begin{array}{l}\text { Withdrawable share capital unique to co- } \\
\text { operative and community benefit society and } \\
\text { organizations. }\end{array}$ & $\begin{array}{l}\text { Investors and } \\
\text { Fundraisers }\end{array}$ \\
\hline $\begin{array}{l}\text { Reward-based } \\
\text { Crowdfunding }\end{array}$ & $\begin{array}{l}\text { Backers have an expectation that fundraisers } \\
\text { (or campaign owners) will provide non- } \\
\text { financial reward(s) or product(s) in exchange } \\
\text { for their contributions. }\end{array}$ & $\begin{array}{l}\text { Backers and Campaign } \\
\text { Owners }\end{array}$ \\
\hline $\begin{array}{l}\text { Donation-based } \\
\text { Crowdfunding }\end{array}$ & $\begin{array}{l}\text { Donations are made by donors usually for } \\
\text { charities and good causes without an } \\
\text { expectation for financial or non-financial } \\
\text { rewards. }\end{array}$ & Donor and Fundraisers \\
\hline $\begin{array}{l}\text { Debt-based } \\
\text { securities }\end{array}$ & $\begin{array}{l}\text { Individuals purchase debentures or long- } \\
\text { term bonds at a fixed interest rate. Lenders } \\
\text { receive full repayment plus interest paid at } \\
\text { maturity. }\end{array}$ & Lenders and Borrowers \\
\hline
\end{tabular}

We also argue that the language used in this taxonomy to describe the different crowdfunding actors, e.g. lender or donor, fundraiser or borrower, is important as it functions to remind analysts and academics of the distinctions, the antecedents, and the processes involved in each distinct model.

\section{Conclusion}

This chapter has sought to demystify, delineate and deconstruct crowdfunding, whilst demonstrating its diversity in a geographical context. We situate crowdfunding within the literature of financial and economic geography and set out to examine an array of highly distinctive crowdfunding models from peer-to-peer consumer lending, equity-based crowdfunding to community shares. We argue that, to truly understand crowdfunding and 
effectively research this fast-evolving phenomenon, it is important to appreciate that various crowdfunding models have different market functions, volume sizes, funding mechanisms, user dynamics and socio-economic impacts.

Specifically, we examined crowdfunding models' diversities and variations in a spatial and regional geography that they manifested, in gender and income profiles, as well as in funder and fundraiser's motivations. We found that, whilst peer-to-peer consumer and business lending models tend to facilitate a more decentralized spatial geography by channelling more funding outflow from London and the South East to the rest of the UK, equity- and rewardbased crowdfunding actually reinforces if not exacerbate the centralized geography of funding, as evidenced in traditional finance by attracting funding inflows to London from other regions. The gendered patterns of several models of crowdfunding, in particular peerto-peer business lending and equity-based crowdfunding, suggest an increasing level of access to new finance for female entrepreneurs. However, the income distribution of fundraisers for the same two prevailing crowdfunding models indicate that crowdfunding marketplace is predominately serving a section of the population that is already well-off and has access to credit from traditional finance channels. The motivations for funders and fundraisers are also highly varied in crowdfunding, with more investment-orientated crowdfunding models attracting funders driven by financial motives, whilst more sociallyorientated models such as community shares, debt-based securities and donation-based crowdfunding having more funders motivated by doing social and environmental good.

Each model has the potential to either challenge or reinforce the status-quo, contributing to the formation of an alternative circuit of finance or merely entrenching the old channels and flows. The extent of "democratization" of finance represented by crowdfunding is certainly stronger in some models than others. These channels and flows can be further teased out through analysing the geography, accessibility, and institutional structure of crowdfunding, while one pronounced feature of many of the different models is the large and growing presence of the mainstream financial players. These may be different financial circuits, but clearly they are not always alternative.

\section{Bibliography}

Agrawal, A., Catalini, C., \& Goldfarb, A. (2011). The Geography of Crowdfunding. NBER Working Paper (w16820).

Bank of England, 2015, Credit Conditions Review, 14. (Accessed on 15 May, 2016) http://www.bankofengland.co.uk/publications/Documents/creditconditionsreview/2016/ccrq4 15.pdf

Beauregard, R. A. (1994). Capital switching and the built environment: United States, 197089. Environment and Planning A, 26(5), 715-732.

Beauhurst, 2015, Total Seed Stage and Venture Stage Equity Investment Statistics, the Deal 2014-2015, Beauhurst, London. 
Belleflamme, P., Lambert, T., \& Schwienbacher, A. (2014). Crowdfunding: Tapping the right crowd. Journal of Business Venturing, 29(5), 585-609.

Bradford, C. S. (2012). Crowdfunding and the federal securities laws. Columbia Business Law Review, 2012(1). Page numbers needed

Brush, C., Greene, P., Balachandra, L., \& Davis, A. (2014). Women Entrepreneurs 2014: Bridging the Gender Gap in Venture Capital. Arthur M.Blank Center for Entrepreneurship Babson College, Wellesley, Massachusetts.

Clark, G. L. (2005). Money flows like mercury: the geography of global finance. Geografiska Annaler: Series B, Human Geography, 87(2), 99-112.

Colombo, M. G., Franzoni, C., \& Rossi-Lamastra, C. (2015). Internal social capital and the attraction of early contributions in crowdfunding. Entrepreneurship Theory and Practice, $39(1), 75-100$.

Dixon, A. D., \& Monk, A. H. (2012). Rethinking the sovereign in sovereign wealth funds. Transactions of the Institute of British Geographers, 37(1), 104-117.

Donald, B., Glasmeier, A., Gray, M., \& Lobao, L. (2014). Austerity in the city: economic crisis and urban service decline?. Cambridge Journal of Regions, Economy and Society, 7(1), 3-15.

Erturk, I., Froud, J., Sukhdev, J., Leaver, A., and Williams, K. 2007. The democratization of finance? Promises, outcomes and conditions. Review of International Political Economy 14: $553-75$.

Fuller, D. and Jonas, A. (2003). Alternative Financial Spaces (Leyshon, A., Lee, R. and Williams, C.) Alternative Economic Spaces. London: Sage.

Fuller, D. (1998). Credit union development: financial inclusion and exclusion. Geoforum, 29(2), 145-157.

Garretsen, H., Kitson, M., \& Martin, R. (2009). Spatial circuits of global finance. Cambridge Journal of Regions, Economy and Society. Volume and page numbers needed

Gatewood, E., Brush, C., Carter, N., Greene, P., and Hart, M. (2004). Women Entrepreneurs, Growth, and Implications for the Classroom, Coleman Foundation white paper series, United States Association for Small Business and Entrepreneurship.

Giddens, A. (2013). The consequences of modernity. Cambridge: Polity Press.

Gotham, K. F. (2009). Creating liquidity out of spatial fixity: the secondary circuit of capital and the subprime mortgage crisis. International Journal of Urban and Regional Research, $33(2), 355-371$.

Griffin, Z. J. (2012). Crowdfunding: fleecing the American masses. Journal of Law Technology and the Internet, 4, 375-410. 
Harvey, D. (1982). Limits to Capital. Oxford: Blackwell.

Harvey, D. (1989). Condition of PostModernity. Oxford: Blackwell.

Harvey, D. (2010). The Enigma of Capital. London: Profile Books.

Kim, K., \& Hann, I. H. (2013). Does crowdfunding democratize access to capital? A geographical analysis. In INFORMS Conference on Information Systems and Technology (CIST).

Kitson, M., Martin, R., \& Tyler, P. (2011). The geographies of austerity. Cambridge journal of regions, economy and society, 4(3), 289-302.

Klagge, B., \& Martin, R. (2005). Decentralized versus centralized financial systems: is there a case for local capital markets?. Journal of Economic Geography, 5(4), 387-421.

Leyshon, A. and Thrift, N. (1997) Money Space. Geographies of Monetary Transformation. London: Routledge.

Lin and Viswanathan (2014). Home Bias in Online Investments: An Empirical Study of an Online Crowdfunding Market. Management Science, 62(5), 1393-1414

Marlow, S., \& Patton, D. (2005). All credit to men? Entrepreneurship, finance, and gender. Entrepreneurship theory and practice, 29(6), 717-735.

Mason, C. and Harrison, R. T. (2002). The geography of venture capital investments in the UK, Transactions of the Institute of British Geographers 27, 427-51.

Martin, R. (1999). Money and the Space Economy. John Wiley \& Sons, London.

Martin, R., \& Turner, D. (2000). Demutualization and the remapping of financial landscapes. Transactions of the Institute of British Geographers, 25(2), 221-241.

Martin, R., Sunley, P., Klaage, B., and Berndt, C. (2003) Regional Venture Capital Policy in Germany and the UK, Anglo-German Foundation: London.

Mollick, E. (2014). The dynamics of crowdfunding: An exploratory study. Journal of Business Venturing, 29(1), 1-16.

Morduch, J. (1999). "The Microfinance Promise." Journal of Economic Literature, 37(4): 1569-1614.

NCVO (2014). UK Civil Society Almanac 2014 - the Voluntary Sector and People. NCVO $\&$ the Third Sector Research Centre (TSRC), London

NewTithing Group (2004). The Generosity of Rich and Poor - How the Newly Discovered "Middle Rich" Stack Up. Publisher details needed 
Nostrum Group (2015). "Unsecured lending market - April 2015"

http://www.nostrumgroup.com/insights/lending/unsecured-lending-market-april-2015/ accessed 25 April 2016.

O'Brien, R. (1992). Global Financial Integration: The End of Geography. London: Royal Institute of International Affairs, Pinter Publishers; 1992.

Pollard, J., \& Samers, M. (2013). Governing Islamic finance: Territory, agency, and the making of cosmopolitan financial geographies. Annals of the Association of American Geographers, 103(3), 710-726.

Pryke, M., 2006. Speculating on geographies of finance. CRESC Working Paper Series 24, Centre for Research on Socio-Cultural Change, University of Manchester and The Open University, Manchester/Milton Keynes, U.K.

Robb, A.M. and Coleman, S. (2009). Sources of financing for new technology firms: a comparison by gender. The Kauffman Foundation. Location needed

Schwartz, A. A. (2013). Crowdfunding Securities. Notre Dame Law Review, 88, 1457.

Shiller, R. J. (2013). Capitalism and financial innovation. Financial Analysts Journal, 69(1).

Shiller, R.J. (2012). Democratize Wall Street, for Social Good. New York Times. April 7, 2012 .

Schwienbacher, A., \& Larralde, B. (2010). Crowdfunding of small entrepreneurial ventures. Handbook of Entrepreneurial Finance, Oxford University Press, Oxford

Tickell, A. (2000). "Finance and Localities" in The Pxford Handbook of Economic Geography numbers and publisher details meeded

UKCES (2015). UK Commission for Employment and Skills, UK Labour Market Projections: 2014-2024 https://www.gov.uk/government/organisations/uk-commission-foremployment-and-skills accessed on 4th May, 2016.

Wójcik, D. (2009) Financial centre bias in primary equity markets. Cambridge Journal of Regions, Economy and Society, 2(2): 193-209.

Zhang, B., Collins, L., \& Swart, R. (2013). The Rise of Future Finance - the UK Alternative Finance Benchmarking Report, Nesta, London.

Zhang, B., Collins, L., \& Baeck, P. (2014). Understanding Alternative Finance - the UK Alternative Finance Industry Report, Nesta, London.

Zhang, B., Wardrop, R., Rau, R., \& Gray, M. (2015). Moving Mainstream: Benchmarking the European Alternative Finance Market. The Journal of Financial Perspectives, December 2015, Volume 3 - Issue 3, London. 60-77 